\title{
Foraging behaviour and habitat use of chick-rearing Australasian Gannets in New Zealand
}

\author{
Gabriel E. Machovsky-Capuska • Mark E. Hauber • Mariela Dassis • \\ Eric Libby • Martin C. Wikelski • Rob Schuckard • David S. Melville • \\ Willie Cook • Michelle Houston • David Raubenheimer
}

\begin{abstract}
Patchily distributed marine pelagic prey present considerable challenges to predatory seabirds, including Gannets (Morus spp.) departing from large breeding colonies. Here, for the first time, we used GPS data loggers to provide detailed spatial, temporal, and habitat metrics of chick-rearing Australasian Gannets (Morus serrator) foraging behaviours from two distant colonies in New Zealand. Our goal was to examine the extent to which Gannet foraging tactics vary across disparate habitats, and determine whether the observed differences are consistent with predictions derived from foraging studies of other gannet species. Foraging trip performance was highly consistent between colonies, and sexes, and no significant differences in any of the variables analyzed were observed. However, Gannets from Farewell Spit (FS) dove in shallower waters
\end{abstract}

Communicated by C. Barbraud.

G. E. Machovsky Capuska $(\bowtie) \cdot D$. Raubenheimer

Faculty of Veterinary Science, Charles Perkins Centre, School of Biological Science, University of Sydney, Sydney, Australia

e mail: g.machovsky@sydney.edu.au

G. E. Machovsky Capuska

Coastal Marine Research Group, Institute of Natural and

Mathematical Sciences, Massey University, Auckland,

New Zealand

M. E. Hauber

Department of Psychology, Hunter College, The Graduate Center of the City University of New York, New York, NY 10065, USA

M. Dassis

Facultad de Ciencias Exactas y Naturales, Instituto de Investigaciones Marinas y Costeras, Universidad Nacional de Mar del Plata CONICET, Funes 3350 (7600),

Mar del Plata, Argentina
(0 $50 \mathrm{~m}$ ) than birds from Cape Kidnappers (CK, >50 m), which is consistent with previous dietary studies suggesting that FS Gannets feed mainly on coastal prey, whereas CK birds feed on species with a more oceanic distribution. Diving frequencies were similar in the two colonies suggesting that Gannets were foraging in habitats with similar levels of food availability. Further studies are needed to understand the relationship between prey availability, oceanography and geographic features, to better interpret foraging tactics of Australasian Gannets.

Keywords Foraging range - Diving behaviour . Morus serrator · Food sources · GPS data loggers · Seabirds

\author{
E. Libby \\ New Zealand Institute for Advanced Study, Institute of Natural \\ Sciences, Massey University, Private Bag 102904 North Shore \\ MSC, Auckland, New Zealand \\ M. C. Wikelski \\ Max Planck Institute for Ornithology, Vogelwarte Radolfzell, \\ Radolfzell, Germany \\ M. C. Wikelski \\ Department of Biology, University of Konstanz, Konstanz, \\ Germany \\ R. Schuckard · D. S. Melville · W. Cook \\ Ornithological Society of New Zealand, Nelson, New Zealand \\ M. Houston \\ Equine Parentage and Animal Genetics Service Centre, \\ Massey University, Palmerston North, New Zealand
}




\section{Zusammenfassung}

Nahrungssuchverhalten und Habitatnutzung Australischer Tölpel während der Jungenaufzucht in Neuseeland

Lückenhaft verbreitete pelagische Beute stellt eine beträchtliche Herausforderung für nahrungssuchende Seevögel dar. Das gilt auch für Tölpel (Morus spp.), die aus großen Brutkolonien zur Nahrungssuche auf See abfliegen. In zwei weit voneinander entfernt liegenden Kolonien Australischer Tölpel (Morus serrator) in Neuseeland wurden nun zum ersten Mal GPS-Datenlogger eingesetzt, um während der Jungenaufzucht detaillierte Raum-Zeit-Daten sowie Informationen zur Habitatnutzung nahrungssuchender Tölpel zu erhalten. Ziel war es zum einen zu untersuchen, in welchem Ausmaß die Nahrungssuchstrategien der Tölpel variieren zwischen verschiedenen Habitaten. Zum anderen wurde bestimmt, ob die beobachteten Unterschiede konsistent sind mit Vorhersagen aus Studien zur Nahrungssuche anderer Tölpelarten. Die NahrungsflugLeistung war einheitlich zwischen den Kolonien und Geschlechtern. Es konnten keine signifikanten Unterschiede zwischen den weiteren analysierten Variablen nachgewiesen werden. Allerdings tauchten Tölpel der Farewell Spit Kolonie (FS) in flacheren Gewässern (0 $50 \mathrm{~m}$ ) als Vögel aus der Cape Kidnappers Kolonie (CK, $>50 \mathrm{~m}$ ). Frühere Nahrungsstudien bestätigen dies und deuten darauf hin, dass FS Tölpel hauptsächlich küstennahe Beute fressen, wohingegen CK Tölpel mehr ozeanisch verbreitete Nahrung aufnehmen. Die Tauchfrequenzen waren ähnlich in beiden Kolonien, was darauf schließen lässt, dass Tölpel in Habitaten mit ähnlichen Beuteverfügbarkeiten auf Nahrungssuche gehen. Weiterführende Untersuchungen zur Beziehung zwischen Beuteverfügbarkeit, Ozeanografie und geografischen Eigenschaften sind nötig, um die Strategien der Nahrungssuche Australischer Tölpel besser zu verstehen und interpretieren zu können.

\section{Introduction}

Marine pelagic resources of predatory seabirds can present considerable challenges because prey is often widely and patchily distributed in space and time (Weimerskirch 2007). Accordingly, successful foraging trips often range over hundreds of kilometres and span several days (Hamer et al. 2000; Rayner et al. 2010). In such circumstances, members of breeding pairs of biparental species need effective long-range foraging strategies to locate the food source and integrated time-budgeting to balance self- feeding, offspring-feeding, and the nutritional constraints of the partner tending the nest (Weimerskirch et al. 1994; Ropert-Coudert et al. 2004; Garthe et al. 2013).

Foraging area could differ between colonies of a single species in relation to regional oceanographic differences, intraspecific competition and food availability (Hamer et al. 2000). Recent advances in bio-logging science, through the development of increasingly miniaturized data loggers, have provided growing details on foraging behaviours and feeding ranges of marine predators, including seabirds (Ropert-Coudert and Wilson 2005). Amongst the three species of closely-related Gannets (Morus spp.), the foraging behaviour of Northern (Morus bassanus) and Cape Gannets (Morus capensis) has been extensively studied using different data loggers. Australasian Gannets (Morus serrator) have been considered to be the southern hemisphere form of the Northern Gannet with similar foraging characteristics, although recent work, based at the breeding colony, suggested that these two distinct species seem to occupy different breeding and foraging niches (Stephenson 2005).

Australasian Gannets breed exclusively in southeastern Australia and New Zealand (Nelson 1978). Despite the recent positive population trends, the species remains the second rarest member of the seabird group Sulidae (Nelson 2005). Within New Zealand, Gannets are distributed among 26 breeding colonies on the east coast and only three on the west coast, spanning a latitudinal range of $3446^{\circ} \mathrm{S}$ (Nelson 2005). Australasian Gannets are known to have a flexible diet of fish and squid, which ranges from coastal to oceanic species with marked prey-use differences between different gannetries (Robertson 1992; Schuckard et al. 2012). The foraging behaviour of this species has been previously characterized using bird bands (Wingham 1985), colour-marked on the chest (Wingham 1985), stable isotopes and capillary tubes (Ismar 2010), direct observations (Wodzicki and Robertson 1955), aerial and underwater filming (Machovsky-Capuska et al. 2011b, 2012, 2013), regurgitations (Wingham 1985; Robertson 1992; Bunce 2001; Pyk et al. 2008; Schuckard et al. 2012), necropsies (Machovsky-Capuska et al. 2011a) and data loggers only in Australian colonies (GPS, Bunce 2005; heart rate, Green et al. 2010).

Here, we report a study in which GPS data loggers were used to examine and compare the behaviour of chickrearing Gannets during foraging trips in two Australasian Gannet colonies from different geographic locations in New Zealand, the Cape Kidnappers (7,300 breeding pairs, east coast) and Farewell Spit (3,900 breeding pairs, west coast) colonies. Recent studies of Northern Gannets (Wakefield et al. 2013) with large sample sizes have quantitatively assessed predictions about the effect of colony size, interspecific competition, oceanographic 
conditions, and food availability on Gannet foraging tactics. While the number of colonies we studied was too low to statistically test these hypotheses, our study will be the first to provide detailed spatial, temporal, and habitat metrics of the Australasian Gannet's foraging behaviours during the breeding season (chick-rearing stage) in two of New Zealand's growing gannetries. In particular, we seek to (1) gain a better understanding of the foraging strategies of Gannets and (2) identify and compare the main foraging areas in which Gannets feed in the two regions.

\section{Methods}

Study area

The study was conducted during the chick-rearing periods in January 2010 and 2011 on the Beach Colony of Cape Kidnappers gannetry (CK), North Island, New Zealand $\left(39^{\circ} 38^{\prime} \mathrm{S}, 177^{\circ} 05^{\prime} \mathrm{E}\right)$ and in January 2012 at Farewell Spit gannetry (FS), which is located at the northern end of the South Island, New Zealand $\left(40^{\circ} 33^{\prime} \mathrm{S} 173^{\circ} 01^{\prime} \mathrm{E}\right)$. CK has a population of around 7,300 breeding pairs (Nelson 2005; Ismar et al. 2010), whereas the FS gannetry has a population estimated at 3,900 breeding pairs (Schuckard et al. 2012).

Capture and handling of birds

Adult Gannets rearing 2- to 5-week-old chicks were captured with a blunt-tip shepherd's crook from nests located in the periphery of the colony immediately after adopting the sky pointing posture (Nelson 1978). Chick age was similar for both colonies. Captured Gannets were banded with individually numbered metal rings on their leg and secondary covert feathers were collected for DNA sex identification following Fridolfsson and Ellegren (1999). The loggers were attached with Tesa tape to the four central tail feathers as in Hamer et al. (2001). To aid in their rapid identification, birds were also marked on the chest with Sharpie markers ${ }^{\circledR}$ (Grémillet et al. 2004). Capturing, measuring and the attachment of loggers took $\sim 10 \mathrm{~min}$, whereafter birds were released at the edge of the colony (Garthe et al. 2007a, b). Devices and tape strips were retrieved soon after the birds arrived at the colony following a single foraging trip. This study was conducted under permits of Massey University Animal Ethics committee (09/76) and the New Zealand Department of Conservation (ECHB-23237-RES).

Data logger deployment

The GPS data loggers were manufactured by e-obs digital telemetry in Germany (http://www.e-obs.de) and consisted
Table 1 Numbers and characteristics of the devices deployed in chick rearing adult Australasian Gannets (Morus serrator) at Cape Kidnappers $(C K)$ and Farewell Spit $(F S)$, New Zealand

\begin{tabular}{lllll}
\hline Colony & Year & Device type & \multicolumn{2}{c}{ Number of birds } \\
\cline { 4 - 5 } & & & M & F \\
\hline CK & \multirow{2}{*}{2010} & GPS continuous & 3 & 4 \\
& & GPS 15 s & 2 & 2 \\
CK & \multirow{2}{*}{2011} & GPS continuous & 5 & 4 \\
& \multirow{2}{*}{ FS } & GPS 15 s & 0 & 1 \\
& \multirow{2}{*}{2012} & GPS continuous & 4 & 4 \\
& & GPS 15 s & 2 & 1 \\
\hline
\end{tabular}

$M$ males, $F$ females

of a power supply (lithium polymer battery cell with $4.5 \mathrm{~V}$ ), a flash memory SD-card, a GPS module (LEA 4S by u-blox ${ }^{\mathrm{TM}}$ ), a radio transmitter ("pinger"), an on-board real-time clock, an antenna, and a mobile interface between user and GPS-RF-tag (Base Station b5; e-obs). All components were embedded into a heat-shrink tube for waterproofing. Final size was $50 \times 50 \times 15 \mathrm{~mm}$ (length $\times$ width $\times$ height), weighing $45 \mathrm{~g}$ and representing around $2 \%$ of the adult body weight (Nelson 1978). To record data related to position (latitude, longitude, and altitude), speed and time, we deployed continuous (1-s intervals) or intermittent (15-s intervals) loggers (Table 1).

Data analysis

Differences in foraging trip parameters were compared between colonies. Following Grémillet et al. (2004), maximum distance away from the colony (MCD), total foraging path, foraging trip duration, flying time, resting time and speed were estimated from the recorded GPS data. The GPS continuous logger offered high resolution data that allowed inferring diving behaviour from the interruptions of GPS signals (Pichegru et al. 2007). In this study, dive duration and dives per hour of trip were estimated as signal interruptions $\leq 8 \mathrm{~s}$, assuming mean dive duration of $8 \mathrm{~s}$ for this species (Machovsky-Capuska et al. 2011b).

Following Pettex et al. (2010), we calculated the average bearing location of the dives from the colony to represent the intended destination. For each day of deployment, we computed the average bearing angle of dives between foraging destinations to quantify the difference in their daily bearing from the colony. Being coastal colonies, the Gannets at both study sites did not have a full range of $360^{\circ}$ available for oceanic foraging trips. To evaluate the probability that the observed distribution of vectors would occur under the null hypothesis of no difference in the bearing direction of foraging trips on the same days, we 
randomised the day assignments of Gannets 100,000 times as part of a permutation test (Robson et al. 2004). Home range areas were calculated applying the adaptive Kernel method (Worton 1989) with 40, 50, 60, 70, 80, 90 and $95 \%$ locations, using the Home Range Tools extension in ArcGIS 9.8. Following Kie et al. (2010), a smoothing factor of $80 \%$ of reference bandwidth was applied to estimate a reliable home range area. All kernel areas are included on the maps; however, only 95 and $50 \%$ values were statistically analysed. As previously described, the $95 \%$ Kernel area (K95) represents the general use area and the $50 \%$ Kernel area (K50) represents the core area or the most intensively used area (Iversen and Esler 2006; Hamer et al. 2007; Rodríguez et al. 2013). K95 and K50 were calculated for both general areas, grouping all birds from each colony and individual areas for each animal.

For statistical comparisons data from the GPS units were analysed using MATLAB 2009 and PASW Statistics v.18. Data were initially tested using Levene's test for homoscedasticity and Shapiro Wilk's test for normality, $\chi^{2}$ and $t$ tests were used for subsequent comparisons. Following Firth et al. (2006) the K95/K50 ratios (the proportion of the general area that were most intensively used) between colonies were $\log _{10}$ transformed and then compared using $t$ tests. We report data as mean \pm standard deviation.

\section{Results}

A total of 32 individual foraging trips were recorded from CK in 2010 and 2011, and FS in 2012 (Table 1). Foraging trip performance was highly consistent between the two consecutive breeding seasons studied at CK colony, with no significant differences in any of the variables analysed (Table 2). Data from both years at CK were therefore

Table 2 Performance of foraging trips made by chick rearing adult Australasian Gannets at Cape Kidnappers in 2010 ( $n$ 11) and 2011 $\left(\begin{array}{ll}n & 9\end{array}\right)$

\begin{tabular}{lcccc}
\hline Parameter & 2010 & 2011 & $t$ value & $p$ \\
\hline $\begin{array}{l}\text { Max. distance to } \\
\text { colony (km) }\end{array}$ & $55.1 \pm 18.7$ & $56.2 \pm 29.3$ & 0.10 & 0.92 \\
$\begin{array}{l}\text { Foraging path } \\
\text { length (km) }\end{array}$ & $255.9 \pm 119.9$ & $282.5 \pm 126.9$ & 0.48 & 0.64 \\
Foraging trip & $37.1 \pm 35.1$ & $25.6 \pm 9.3$ & 0.96 & 0.35 \\
$\quad$ duration (h) & & & & \\
Speed (km h $\left.{ }^{-1}\right)$ & $8.5 \pm 3.4$ & $11.4 \pm 4.5$ & 1.68 & 0.11 \\
Flying time (h) & $5.6 \pm 2.5$ & $5.7 \pm 2.6$ & 0.08 & 0.93 \\
Resting time (h) & $31.5 \pm 35.4$ & $19.8 \pm 8.6$ & 0.96 & 0.35 \\
Dive duration (s) & $4.0 \pm 2.1$ & $3.9 \pm 2.1$ & 1.02 & 0.98 \\
Dives per hour of & $4.2 \pm 1.3$ & $4.2 \pm 1.2$ & 0.01 & 0.92 \\
trip & & & & \\
\hline
\end{tabular}

Values are given as mean \pm standard deviation combined and pooled for multiple comparisons with data collected from FS colony.

Foraging trip performance was highly consistent between colonies and no significant differences in any of the variables analysed were observed (Table 3). During foraging trips, Gannets spent on average $23.5 \%( \pm 7.5)$ of the time flying at $\mathrm{CK}$ and $29.0 \%( \pm 21.9)$ at FS, whereas they rested on the water an average of $75.5 \%( \pm 7.4)$ of the time at $\mathrm{CK}$ and $70.1 \%( \pm 21.9)$ at FS. Overall, plungediving only accounted for $<1 \%$ of the foraging trip in both colonies.

From a total of 2,206 dives recorded, 521 dives were from FS and 1,685 dives were from CK (808 dives in 2010 and 877 dives in 2011). No significant differences were observed in the duration and frequency of the dives between colonies (Table 3), Gannets from FS dove in shallower waters $(99.8 \%, 050 \mathrm{~m}$ isobaths; Fig. 1) than Gannets from CK (54.5\%, >50 m isobaths; Fig. 2) (Chi square test, $\chi^{2}=481.25$; df $\left.=1 ; p<0.0001\right)$.

The K95 and K50 used by Gannets from CK colony were similar between years ( $t$ test, $t=-1.09, d f=20$, $p=0.29$ and $t$ test, $t=-1.32, d f=20, \quad p=0.20$, respectively) and were therefore combined for the analyses, resulting in 4,964.1 and $755.7 \mathrm{~km}^{2}$, respectively (Fig. 1),

Table 3 Colony characteristics and foraging trip performance of Australasian Gannets breeding at Cape Kidnappers and Farewell Spit

\begin{tabular}{|c|c|c|c|c|}
\hline Parameter & Cape Kidnappers & Farewell Spit & $t$ value & $p$ \\
\hline $\begin{array}{c}\text { Geographic } \\
\text { location }\end{array}$ & $\begin{array}{l}\text { East coast } \\
\quad \text { (North Island) }\end{array}$ & $\begin{array}{l}\text { West coast } \\
\text { (South Island) }\end{array}$ & & \\
\hline Population size & 7,300 & 3,900 & & \\
\hline Sample size $(n)$ & 21 & 11 & & \\
\hline $\begin{array}{l}\text { Max. distance } \\
\text { to colony } \\
(\mathrm{km})\end{array}$ & $55.6 \pm 23.3$ & $40.2 \pm 28.2$ & 1.63 & 0.12 \\
\hline $\begin{array}{l}\text { Foraging path } \\
\text { length }(\mathrm{km})\end{array}$ & $267.9 \pm 120.6$ & $184.6 \pm 188.9$ & 2.03 & 0.05 \\
\hline $\begin{array}{l}\text { K95 } \\
\text { individuals } \\
\left(\mathrm{km}^{2}\right)\end{array}$ & $1,854.4 \pm 1,312.0$ & $1,061.9 \pm 1,681.9$ & 1.45 & 0.16 \\
\hline $\begin{array}{l}\text { K50 } \\
\text { individuals } \\
\left(\mathrm{km}^{2}\right)\end{array}$ & $167.2 \pm 131.4$ & $108.0 \pm 190.6$ & 1.02 & 0.32 \\
\hline $\begin{array}{l}\text { Foraging trip } \\
\text { duration (h) }\end{array}$ & $31.9 \pm 26.8$ & $14.7 \pm 10.7$ & 1.50 & 0.14 \\
\hline $\begin{array}{l}\text { Speed } \\
\qquad(\mathrm{km} \mathrm{h}\end{array}$ & $9.8 \pm 4.1$ & $15.3 \pm 16.1$ & 1.46 & 0.16 \\
\hline Flying time (h) & $5.7 \pm 2.5$ & $4.4 \pm 4.1$ & 1.23 & 0.23 \\
\hline $\begin{array}{l}\text { Resting time } \\
\text { (h) }\end{array}$ & $26.2 \pm 26.9$ & $10.3 \pm 7.7$ & 1.88 & 0.07 \\
\hline $\begin{array}{l}\text { Dive duration } \\
\text { (s) }\end{array}$ & $4.1 \pm 2.2$ & $3.9 \pm 2.1$ & 1.92 & 0.05 \\
\hline $\begin{array}{l}\text { Dives per hour } \\
\text { of trip }\end{array}$ & $4.2 \pm 1.2$ & $4.8 \pm 1.1$ & 1.15 & 0.26 \\
\hline
\end{tabular}

Values are given as mean \pm standard deviation 
Fig. 1 Locations of the diving activities by Australasian Gannets (Morus serrator) foraging from Farewell Spit, New Zealand. Star the location of the colony, dots the positions of the dives and kernel polygons the foraging home ranges. Isobaths expressed in meters (m)

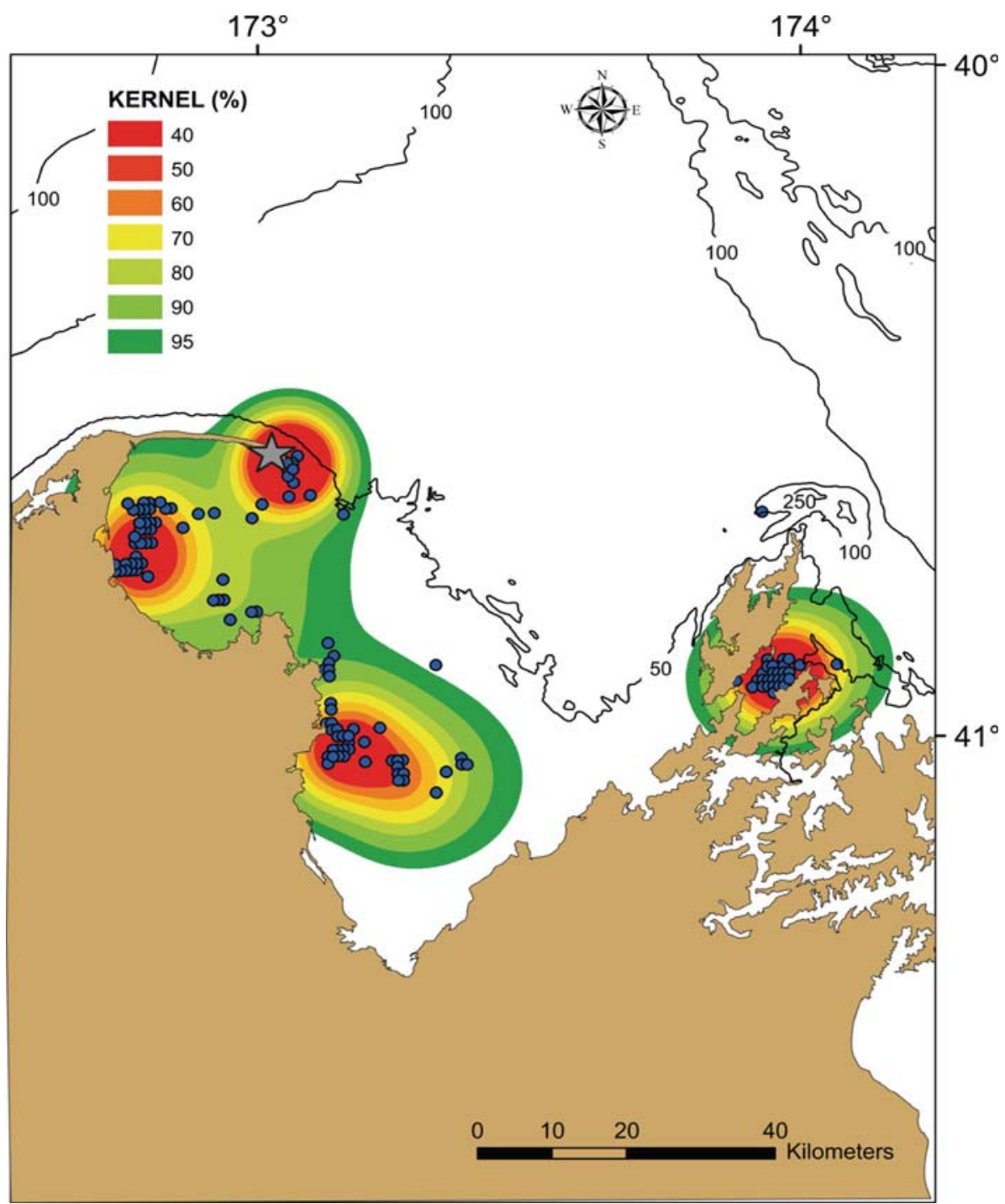

whereas the marine areas used by FS Gannets were 3,786.2 and $689.1 \mathrm{~km}^{2}$ for $\mathrm{K} 95$ and $\mathrm{K} 50$ respectively (Fig. 2). Despite the CK areas having slightly larger values compared to the FS areas, no significant differences between colonies were found in either the K95 or the K50 area distributions (Table 3). Individual kernel ranges showed a high variability among Gannets in both colonies: K95 ranged from 417.94 to $5,158.86 \mathrm{~km}^{2}(\mathrm{CV}=70.75 \%)$ and $\mathrm{K} 50$ from 27.16 to $485.30 \mathrm{~km}^{2}(\mathrm{CV}=78.63 \%)$ in $\mathrm{CK}$ colony, and K95 from 0.74 to $5,922.69 \mathrm{~km}^{2}$ $(\mathrm{CV}=158.38 \%)$ and $\mathrm{K} 50$ from 0.04 to $533.61 \mathrm{~km}^{2}$ $(\mathrm{CV}=176.47 \%)$ in FS colony. Again, no significant differences were found in the ratios K95:K50 areas between CK $(9.4 \pm 3.7 \%$, range $=3.217 .6 \%)$ and FS $(9.3 \pm 8.0 \%$, range $=3.829 .3 \%) \quad(t$ test, $t=-0.89$, $d f=29, p=0.38)$.
The bearing angles of departing birds deployed on the same day at FS ( $n=4$ groups, eight birds) showed that the majority of tracked FS Gannets foraged southeast of the colony (Chi square test, $\chi^{2}=7.36 ; d f=2 ; p<0.05$ ), which corresponds to both a general use of area (K95) and a core foraging area (K50) almost fully included within the $050 \mathrm{~m}$ isobaths (Fig. 2). However, CK Gannets $(n=6$ groups, 18 birds) dispersed along north-eastern bearingangles of their colony (Chi square test, $\chi^{2}=13.71 ; d f=2$; $p<0.001$ ), used deeper areas (K95, $35.8 \%$, and K50, $51.9 \%$ overlapping the $50100 \mathrm{~m}$ isobaths) and ranged into areas of $1,000 \mathrm{~m}$ isobaths (K95, $23.3 \%$ overlapping 100 1,000 m isobaths, Fig. 1). A permutation test revealed that the average angle of bearing between Gannets deployed on the same day was not significantly different than random $(n=10, p>0.05)$. 
Fig. 2 Locations of the diving activities by Australasian Gannets foraging from Cape the location of the colony, dots the positions of the dives and kernel polygons the foraging home ranges. Isobaths expressed in meters $(\mathrm{m})$ Kidnappers, New Zealand. Star

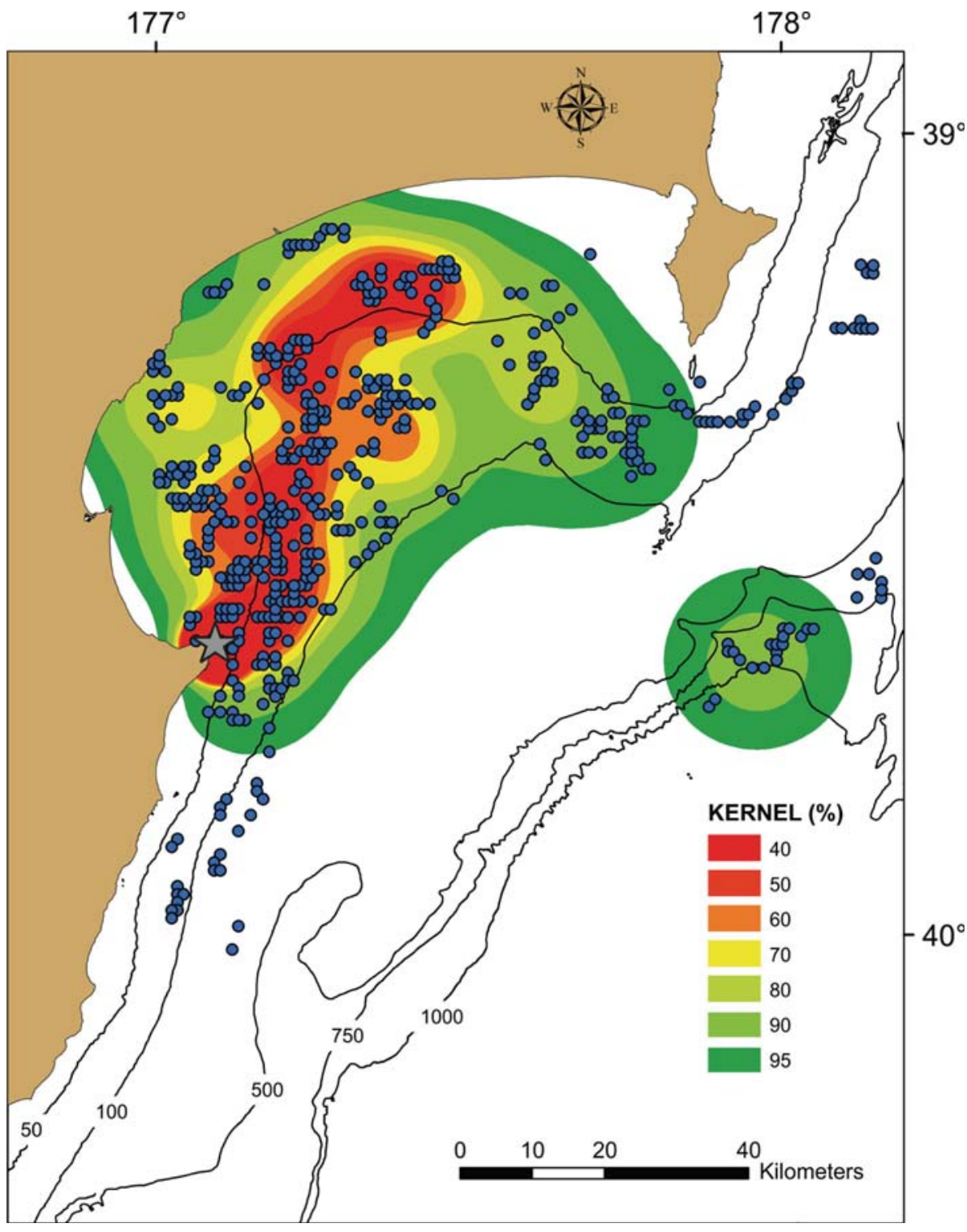

There were no significant differences between the sexes in the foraging performance and neither in the areas in which Gannets concentrated their foraging activity (Table 4).

\section{Discussion}

Seabirds, including Gannets, spend most of their lives over the open ocean foraging in diverse marine environments (Lack 1968). These challenges are particularly pronounced for breeding Gannets, which are face additional foraging demands to feed their growing offspring and also increased risk of injury associated with diving more frequently (Machovsky-Capuska et al. 2011a). Spatial and temporal fluctuations in prey concentrations create challenges for foraging (Weimerskirch 2007; MachovskyCapuska et al. 2011b). Here, for the first time, we report foraging behaviour and home range in Australasian Gannets from two different colonies in New Zealand using bird-attached data loggers. As in previous studies on Gannets with similar devices (Garthe et al. 2003, 2007a, b; Grémillet et al. 2004; Moseley et al. 2012), we did not find any detectable effect of our work on the birds' behaviour on land.

Trip duration and time spent flying and resting were similar between colonies and consistent with previous findings for the same species by Bunce (2005), and for the congenerics Cape Gannets Moseley et al. (2012) and Northern Gannets (Garthe et al. 2007a). The similarities in their performance suggest that these three geographically different species balance their foraging behaviour in a similar manner.

Australasian Gannets from CK covered foraging distances that were similar in range to those of their 
Table 4 Foraging performance of male $(M)$ and female $(F)$ Australasian Gannets breeding at Farewell Spit $(M \quad 6$ and $F \quad$ 5) and Cape

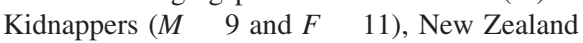

\begin{tabular}{|c|c|c|c|c|c|}
\hline Parameter & Colony & Males & Females & $t$ value & $p$ \\
\hline \multirow[t]{2}{*}{ Max. distance to colony $(\mathrm{km})$} & FS & $36.4 \pm 36.6$ & $44.8 \pm 16.2$ & 0.47 & 0.65 \\
\hline & CK & $62.7 \pm 27.9$ & $49.7 \pm 18.1$ & 1.26 & 0.22 \\
\hline \multirow[t]{2}{*}{ Foraging path length (km) } & FS & $209.6 \pm 246.9$ & $154.6 \pm 104.9$ & 0.46 & 0.65 \\
\hline & CK & $281.2 \pm 119.6$ & $257.0 \pm 126.0$ & 0.44 & 0.67 \\
\hline \multirow[t]{2}{*}{ K95 $\left(\mathrm{km}^{2}\right)$} & FS & $1,254.7 \pm 2,307.5$ & $830.5 \pm 543.5$ & 0.40 & 0.70 \\
\hline & CK & $2,288.9 \pm 1,573.2$ & $1,498.9 \pm 990.8$ & 1.37 & 0.19 \\
\hline \multirow[t]{2}{*}{$\mathrm{K} 50\left(\mathrm{~km}^{2}\right)$} & FS & $103.6 \pm 211.3$ & $113.3 \pm 186.9$ & 0.08 & 0.94 \\
\hline & CK & $190.0 \pm 127.5$ & $148.5 \pm 137.7$ & 0.69 & 0.50 \\
\hline \multirow[t]{2}{*}{ Foraging trip duration (h) } & FS & $16.4 \pm 12.5$ & $12.7 \pm 6.7$ & 0.32 & 0.75 \\
\hline & CK & $39.3 \pm 38.8$ & $25.9 \pm 8.3$ & 1.11 & 0.28 \\
\hline \multirow[t]{2}{*}{ Speed $\left(\mathrm{km} \mathrm{h}^{-1}\right)$} & FS & $10.4 \pm 7.4$ & $10.3 \pm 4.4$ & 1.12 & 0.30 \\
\hline & CK & $9.4 \pm 3.8$ & $10.1 \pm 4.5$ & 0.38 & 0.70 \\
\hline \multirow[t]{2}{*}{ Flying time (h) } & FS & $5.1 \pm 5.5$ & $3.2 \pm 2.4$ & 0.75 & 0.47 \\
\hline & CK & $5.8 \pm 2.6$ & $5.6 \pm 2.4$ & 0.25 & 0.80 \\
\hline \multirow[t]{2}{*}{ Resting time (h) } & FS & $11.3 \pm 8.7$ & $9.5 \pm 7.1$ & 0.77 & 0.46 \\
\hline & CK & $33.4 \pm 39.3$ & $20.3 \pm 7.7$ & 1.08 & 0.29 \\
\hline \multirow[t]{2}{*}{ Dive duration (s) } & FS & $4.2 \pm 1.5$ & $3.9 \pm 1.8$ & 0.63 & 0.54 \\
\hline & CK & $4.4 \pm 2.2$ & $3.7 \pm 2.5$ & 0.45 & 0.85 \\
\hline \multirow[t]{2}{*}{ Dives per hour of trip } & FS & $4.0 \pm 0.4$ & $4.7 \pm 1.4$ & 0.97 & 0.37 \\
\hline & CK & $4.5 \pm 0.7$ & $4.1 \pm 1.5$ & 0.72 & 0.49 \\
\hline
\end{tabular}

Values are given as mean \pm standard deviation

conspecifics from FS (Table 3). Wingham (1985) suggested a larger foraging range (mean $=268 \mathrm{~km}$ for $\mathrm{CK}$ ) than reported by us, although that study was based on a mark recapture method involving birds marked with paint on their chests. In contrast, the results from our study are similar to those distance ranges (mean $=52.7 \mathrm{~km}$ ) recorded by Bunce (2005) using GPS loggers in Australia, presumably reflecting similarities in the foraging behaviour of these marine predators in different habitats off distant coastal areas within their natural distribution.

Wild and laboratory foraging animals exploit their environment in a way that reflects the distribution of food sources (Grémillet et al. 2004). Individual kernel ranges showed a high variability among Gannets in both colonies, suggesting that individual experience and memory could serve as an orientation factor for patch detection as it has been proposed to be important to Atlantic Gannets (Hamer et al. 2007; Pettex et al. 2010) and Cape Gannets (Grémillet et al. 2004). Overall, foraging range sizes used by Australasian Gannets were similar between colonies, and most individuals tended to concentrate their at-sea activities similarly in areas of $\sim 10 \%$ of the maximum explored range (Figs. 1, 2). Bearing angles of departing birds deployed on the same day in both colonies also corresponded to foraging areas exploited by Australasian Gannets. These concentrated areas around FS (Golden, Tasman and Admiralty Bays) and CK (Hawke Bay) are well known as high primary marine productive zones for their blooms in nutrient-rich diatoms during the breeding season of Gannets (Heath 1985; Paul et al. 2001).

Bathymetry has been suggested to be an important foraging parameter related to the habitat use of the prey captured by Gannets (Hamer et al. 2000; Garthe et al. 2007a). Our results showed that Gannets from FS dived in shallower waters $(050 \mathrm{~m})$ than birds from CK $(>50 \mathrm{~m})$. This result is consistent with findings by Schuckard et al. (2012), who showed that Australasian Gannets on FS feed mainly on coastal species (pilchard and anchovy Engraulis australis), and also by Robertson (1992), who showed that Gannets at CK fed on species with a more oceanic distribution (saury Scomberesox saurus, khawai Arripis trutta and cubiceps Cubiceps caeruleus). The diving frequency during trips documented in our study for both colonies (CK 4.2 and FS 4.8 dive $\mathrm{h}$ trip $^{-1}$ ) was higher than that previously reported for Australasian Gannets (2.6 dive h trip ${ }^{-1}$; Green et al. 2010), Cape Gannets (3.8 and 2.8 dive h trip ${ }^{-1}$; Moseley et al. 2012) and for Northern Gannets (1.35 dive $h$ trip $^{-1}$; Lewis et al. 2004). It has been suggested that dive frequency may be used as a good proxy for prey encounter rate in this species (Lewis et al. 2004), especially given the high success in prey capture (72\%; Machovsky-Capuska et al. 2012). Diving frequencies were similar in both 
colonies, suggesting that Gannets were foraging in habitats with similar levels of food availability.

Colony size has been suggested to increase intraspecific competition and interference on food sources by diffusing them farther away and subsequently augmenting the distance that Gannets need to travel for food (Lewis et al. 2001; Camphuysen 2011). Northern Gannets from larger colonies travelled longer distances than conspecifics from smaller colonies (Garthe et al. 2007a; Wakefield et al. 2013). However, it is not clear whether this pattern is generally applicable to all three Gannet species, because different studies on Cape Gannets showed opposite patterns to one another (Pichegru et al. 2007; Moseley et al. 2012). In our study, despite the fact that CK has almost twice the number of breeding pairs than FS, and hence likely generates greater competition for food, no significant differences in foraging ranges were observed between these two colonies. Similar findings were reported by Moseley et al. (2012) from different sized colonies of the Cape Gannet. However, interpretation of this result is subject to the caveat that our sample sizes were small, and we were unable to collect data from both colonies in the same breeding season. On this basis, we suggest that the influence of intraspecific competition in foraging performance requires further investigation for this species.

Sex is also known to influence Gannet foraging behaviour (Lewis et al. 2001; Ismar et al. 2010; Mullers and Navarro 2010; Stauss et al. 2012). Again, subject to the caveat of small sample sizes, we detected no statistical sex differences in foraging trip parameters and in the use of particular foraging areas. These results are consistent with the findings of Bunce (2005) for Australasian Gannets and Lewis et al. (2002) and Garthe et al. (2007a) for Northern Gannets. In spite of the difficulties that monomorphic species such as Gannets present (Nelson 1978), we still need more data on fine-scale foraging behaviour and predatory tactics to further compare patterns between the sexes of the Australasian Gannet.

Our work has provided extensive quantitative details towards gaining a better understanding of the relationship between prey availability, oceanography and geographic features, and variability in the foraging tactics of Australasian Gannets across different spatial and temporal scales. This work, and future extensions, will also be informative regarding the assessment of the impact of commercial fisheries in Gannet foraging areas around New Zealand. As a next step, a wider range of Gannet colonies within New Zealand and also between New Zealand and Australia should be included in the comparison, as was done for numerous colonies of the Northern Gannet by Lewis et al. (2001) and Wakefield et al. (2013).
Acknowledgments We acknowledge T. Fettermann, S. Clements, A. Boyer, L. Meynier, L. van Zonneveld, T. Greenawalt, E. Martínez, K. and S. Machovsky, J. Melville and S. Ismar for assistance in the field. We also thank the Napier Department of Conservation office for the permission to use the ranger's house during field work and the Cape Kidnappers landowners and farm managers for access to their property. The Department of Conservation, Golden Bay kindly allowed use of their house at Farewell Spit and transport was provided by Paddy Gillooly of Farewell Spit Ecotours. We thank E. Martínez, S. Dwyer, R. Mullers, P. Battley, J. Waas, C. Moseley, L. Pichegru and F. Bairlein for helpful comments on early versions of the man uscript. This research was funded by National Geographic Waitt Grant, Massey University and Faculty of Veterinary Science Research Funds.

\section{References}

Bunce A (2001) Prey consumption of Australasian gannets (Morus serrator) breeding in Port Phillip Bay, southeast Australia, and potential overlap with commercial fisheries. ICES J Mar Sci 58:904 915

Bunce A (2005) Individual foraging strategies in Australasian gannets (Morus serrator). In Biuw M, Hooker S, McConnell B, Miller P, Sparling C (eds), 2nd International Bio logging Science Sym posium: programme and abstracts. Sea Mammal Research Unit, University of St Andrews, p 42

Camphuysen K (2011) Northern gannets in the North Sea: foraging distribution and feeding techniques around the bass rock. $\mathrm{Br}$ Birds 104:60

Firth RS, Woinarski JC, Noske RA (2006) Home range and den characteristics of the brush tailed rabbit rat (Conilurus penicill atus) in the monsoonal tropics of the Northern territory, Australia. Wildl Res 33:397 407

Fridolfsson AK, Ellegren H (1999) A simple and universal method for molecular sexing of non ratite birds. J Avian Biol 30:116 121

Garthe S, Benvenuti S, Montevecchi WA (2003) Temporal patterns of foraging activities of northern gannets Morus bassanus in the north west Atlantic. Can J Zool 81:453 461

Garthe S, Montevecchi WA, Chapdelaine G, Rail JF, Hedd A (2007a) Contrasting foraging tactics by northern gannets (Sula bassana) breeding in different oceanographic domains with different prey fields. Mar Biol 151:687 694

Garthe S, Montevecchi WA, Davoren GK (2007b) Flight destinations and foraging behaviour of northern gannets (Sula bassana) preying on a small forage fish in a low arctic ecosystem. Deep Sea Res Part II 54:311 320

Garthe S, Guse N, Montevecchi WA, Rail J, Grégoire F (2013) The daily catch: flight altitude and diving behaviour of northern gannets feeding on Atlantic mackerel. J Sea Res. doi:10.1016/j. seares.2013.07.020

Green JA, White CR, Bunce A, Frappell PB, Butler PJ (2010) Energetic consequences of plunge diving in gannets. Endang Spec Res 10:269 279

Grémillet D, Dell'Omo G, Ryan P, Peters G, Ropert Coudert Y, Weeks S (2004) Offshore diplomacy, or how seabirds mitigate intra specific competition: a case study based on GPS tracking of Cape gannets from neighbouring colonies. Mar Ecol Prog Ser, i 265279

Hamer KC, Phillips RA, Wanless S, Harris MP, Wood AG (2000) Foraging ranges, diets and feeding locations of gannets (Morus bassanus) in the North Sea: evidence from satellite telemetry. Mar Ecol Prog Ser 200:257 264 
Hamer KC, Phillips RA, Hill J, Wanless S, Wood AG (2001) Contrasting foraging strategies of gannets (Morus bassanus) at two North Atlantic colonies: foraging trip duration and foraging area fidelity. Mar Ecol Prog Ser 224:283 290

Hamer KC, Humphreys EM, Garthe S, Hennicke J, Peters G, Grémillet D, Phillips RA, Harris MP, Wanless S (2007) Annual variation in diets, feeding locations and foraging behaviour of gannets in the North Sea: flexibility, consistency and constraint. Mar Ecol Prog Ser 338:295 305

Heath RA (1985) A review of the physical oceanography of the seas around New Zealand. NZ J Mar Freshw Res 19:79 124

Ismar SMH (2010) Foraging and breeding ecology of the Australasian gannet Morus serrator, with applications for rare New Zealand seabirds. PhD thesis, The University of Auckland, Auckland

Ismar SMH, Daniel C, Stephenson B, Hauber M (2010) Mate replacement entails a fitness cost for a socially monogamous seabird. Naturwissenschaften 97:109 113

Iversen SA, Esler D (2006) Site fidelity and the demographic implications of winter movements by a migratory bird, the harlequin duck Histrionicus histrionicus. J Avian Biol $37: 219228$

Kie JG, Matthiopoulos J, Fieberg J, Powell RA, Cagnacci F, Mitchell MS, Gaillard JM, Moorcroft PR (2010) The home range concept: are traditional estimators still relevant with modern telemetry technology? Philos Trans R Soc Lond B 365:2221 2231

Lack D (1968) Ecological adaptations for breeding in birds. Methuen, London

Lewis S, Sherratt TN, Hamer KC, Wanless S (2001) Evidence of intra specific competition for food in a pelagic seabird. Nature 412:816 819

Lewis S, Benvenuti S, Dall Antonia L, Griffiths R, Money L, Sherratt TN, Wanless S, Hamer KC (2002) Sex specific foraging behaviour in a monomorphic seabird. Proc R Soc Lond B 269:1687 1693

Lewis S, Benvenuti S, Daunt F, Wanless S, Dall'Antonia L, Luschi P, Elston DA, Hamer KC, Sherratt TN (2004) Partitioning of diving effort in foraging trips of northern gannets. Can $\mathrm{J}$ Zool 82:1910 1916

Machovsky Capuska GE, Dwyer SL, Alley MR, Stockin KA, Raubenheimer D (2011a) Evidence for fatal collisions and kleptoparasitism while plunge diving in gannets. Ibis 153:631 635

Machovsky Capuska GE, Vaughn RL, Würsig B, Katzir G, Rauben heimer D (2011b) Dive strategies and foraging effort in Australasian gannets (Morus serrator). Mar Ecol Prog Ser 442:255 261

Machovsky Capuska GE, Howland HC, Vaughn RL, Würsig B, Raubenheimer D, Hauber ME, Katzir G (2012) Visual accom modation and active pursuit of prey underwater in a plunge diving bird: the Australasian gannet. Proc R Soc Lond B 279:4118 4125

Machovsky Capuska GE, Vaughn Hirshorn RL, Würsig B, Rauben heimer D (2013) Can gannets define their diving profile prior to submergence? Notornis 60:255 257

Moseley C, Grémillet D, Connan M, Ryan PG, Mullers RH, van der Lingen CD, Miller TW, Coetzee JC, Crawford RJM, Sabarros P, McQuaid CD, Pichegru L (2012) Foraging ecology and ecophysiology of Cape gannets from colonies in contrasting feeding environments. J Exp Mar Biol Ecol 422:29 38

Mullers RHE, Navarro RA (2010) Foraging behaviour of Cape gannets as an indicator of colony health status. Endang Spec Res 12:193 202

Nelson JB (1978) The sulidae: gannets and boobies. Oxford University Press, Oxford

Nelson JB (2005) Pelicans, cormorants and their relatives. Oxford University Press, Oxford
Paul LJ, Taylor PR, Parkinson DM (2001) Pilchard (Sardinops neopilchardus) biology and fisheries in New Zealand, and a review of pilchard (Sardinops, Sardina) biology, fisheries, and research in the main world fisheries. New Zealand Fisheries Assessment Report 200U37

Pettex E, Bonadonna F, Enstipp MR, Siorat F, Grémillet D (2010) Northern gannets anticipate the spatio temporal occurrence of their prey. J Exp Biol 213:2365 2371

Pichegru L, Ryan PG, van der Lingen CD, Coetzee J, Ropert Coudert Y, Grémillet D (2007) Foraging behaviour and energetics of Cape gannets Morus capensis feeding on live prey and fishery discards in the Benguela upwelling system. Mar Ecol Prog Ser 350:127 136

Pyk TM, Bunce A, Norman FI (2008) The influence of age on reproductive success and diet in Australasian gannets (Morus serrator) breeding at Pope's eye, Port Phillip Bay, Victoria. Austr J Zool 55:267 274

Rayner MJ, Hartill BW, Hauber ME, Phillips RA (2010) Central place foraging by breeding Cook's petrel (Pterodroma cookii): foraging duration reflects range, diet and chick meal mass. Mar Biol 157:2187 2194

Robertson D (1992) Diet of the Australasian gannet (Morus serrator, G.R. Gray) around New Zealand. NZ J Ecol 16:77 81

Robson BW, Goebel ME, Baker JD, Ream RR, Loughlin TR, Francis RC, Antonelis GA, Costa DP (2004) Separation of foraging habitat among breeding sites of a colonial marine predator, the northern fur seal (Callorhinus ursinus). Can J Zool 82:20 29

Rodríguez D, Dassis M, Ponce de León A, Bastida R, Barreiro C, Farenga M, Davis R (2013) Foraging areas of female Southern sea lions (Otaria flavescens) on La Plata River estuary (Argen tina Uruguay). Deep Sea Res II 88 89:120 130

Ropert Coudert Y, Wilson RP (2005) Trends and perspectives in animal attached remote sensing. Front Ecol Environ 3:437 444

Ropert Coudert Y, Grémillet D, Kato A, Ryan P, Naito Y, Le Maho Y (2004) A fine scale time budget of Cape gannets provides insights into the foraging strategies of coastal seabirds. Anim Behav 67:985 992

Schuckard R, Melville D, Cook W, Machovsky Capuska GE (2012) Diet of the Australasian gannet (Morus serrator) at farewell spit, New Zealand. Notornis 59:66 70

Stauss C, Bearhop S, Bodey TW, Garthe S, Gunn C, Grecian WJ, Votier SC (2012) Sex specific foraging behaviour in northern gannets Morus bassanus: incidence and implications. Mar Ecol Prog Ser 457:151 162

Stephenson B (2005) Variability in the breeding ecology of Austral asian gannets (Morus serrator) at Cape Kidnappers, New Zealand. PhD thesis, Massey University, New Zealand

Wakefield ED, Bodey TW, Bearhop S, Blackburn J, Colhoun K, Davies R, Dwyer RG, Green JA, Grémillet D, Jackson AL, Jessopp MJ, Kane A, Langston RH, Lescroël A, Murray S, Le Nuz M, Patrick SC, Péron C, Soanes LM, Wanless S, Votier SC, Hamer KC (2013) Space partitioning without territoriality in gannets. Science 341:68 70

Weimerskirch H (2007) Are seabirds foraging for unpredictable resources? Deep Sea Res Part II 54:211 223

Weimerskirch H, Chastel O, Ackermann L, Chaurand T, Cuenot Chaillet F, Hindermeyer X, Judas J (1994) Alternate long and short foraging trips in pelagic seabird parents. Anim Behav 47:472 476

Wingham EJ (1985) Food and feeding range of the Australasian gannet Morus serrator (Gray). Emu 85:231 239

Wodzicki K, Robertson F (1955) Observations on diving of Austral asian gannet. Notornis 6:72 76

Worton BJ (1989) Kernel methods for estimating the utilization distribution in home range studies. Ecology 70:164 168 